\title{
VARIEDADES
}

\section{EL TÍTULO DE LA CRÓNICA ALMOHADE DE IBN ȘĀHIB AL-ṢALĀT}

\author{
MARIBEL FIERRO \\ CSIC - Madrid
}

Uno de los cronistas más importantes de los almohades fue el andalusí Abū Marwān c Abd al-Malik b. Muḥammad b. Aḥmad b. Muhammad b. Ibrāhīm al-Bāŷì, conocido como Ibn Șāhịib al-ṣalāt (fallecido después de 600/1203). Su crónica del califato inaugurado por ${ }^{c} \mathrm{Abd}$ al-Mu'min sólo se ha conservado parcialmente y lleva el título de al-Mann bi-l-imäma calà l-musta ${ }^{c} a f i n a ~ b i-a n ~ \hat{y} a^{c}$ ala-hum Allāh a'imma wa-ŷa ala-hum al-wāritīin wa-zuhür al-imām Mahdī al-muwahhidin ${ }^{1}$. Huici Miranda tradujo ese título como «El don del imamato para los que no merecieron que los colocase Dios como imames y los puso como sus herederos y la aparición de al-Mahdī de los almohades», de donde se deduciría que los almohades mismos (recuérdese que Ibn Șāhib al-ṣalāt formaba parte de los talaba, los «cuadros» almohades) no estaban muy convencidos de su propia legitimidad religiosa y política. La traducción de Huici Miranda ha influido a investigadores posteriores ${ }^{2}$, a pesar de que ya el editor del texto árabe, ${ }^{\mathrm{C}} \mathrm{Abd}$ al-Hādī al-Tāzī, había señalado la estrecha conexión de ese título con un versículo coránico ${ }^{3}$, el cual contribuye a aclarar su significado.

\footnotetext{
${ }^{1}$ Sobre el autor v. $E I^{2}$, III, 949 [J.F.P. Hopkins], pero especialmente al-Tāzī, c Abd al-Hādī (editor de la crónica) en Maŷallat al-Maŷma al-'Ilmī al-'iräqī 11 (1964), 243-274 y en la introducción a su edición de la crónica. Se conserva un único manuscrito de al-Mann bi-l-imãma (en la Biblioteca Bodleiana de Oxford), del que hay copia en la Biblioteca General de Rabat, n. ${ }^{\circ} 2649 \mathrm{da} l$. El texto fue editado por ${ }^{\mathrm{C}} \mathrm{Abd}$ al-Hādī al-Tāzī,

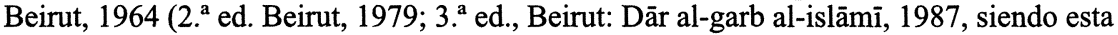
última la que utilizo) y traducido por Ambrosio Huici Miranda, Valencia, 1969.

${ }^{2} \mathrm{~V}$. por ejemplo El retroceso territorial en al-Andalus. Almorávides y almohades. Siglos XI al XIII, vol. VIII/2 de la Historia de España Ramón Menéndez Pidal, coord. María Jesús Viguera, Madrid: Espasa Calpe, 1997, p. 10, donde se recoge la siguiente traducción: «Don del imamato a quienes no correspondía que Dios les hiciera imames ni les concediera ser herederos [de la soberanía], y aparición del Imam Mahdī de los almohades».

${ }^{3}$ V. la introducción a la edición del texto árabe, p. 27.
}

Al-Qantara XXIV, 2 (2003) 291-294 
Ese versículo coránico se encuentra en la azora 28 («El relato») y forma parte de la historia de Moisés y Faraón que en ella se narra. Faraón, se dice en el versículo 4, «se condujo altivamente en el país [Egipto] y dividió a sus habitantes en clanes. Debilitaba a uno de ellos, degollando a sus hijos varones y dejando con vida a sus mujeres. Era de los corruptores», pero entonces, dice Dios (versículo 5):

Quisimos favorecer a los que habían sido humillados [es decir, los israelitas] en el país y hacer de ellos jefes, hacer de ellos herederos [de sus opresores]

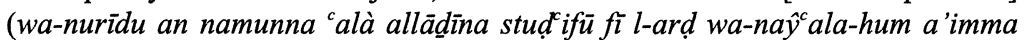
wa-nầं ala-hum al-wārițina),

continuándose en el versículo siguiente: «darles poderío en el país y servirnos de ellos para hacer que Faraón, Hamán y sus ejércitos experimentaran lo que ya recelaban ...» (traducción de Julio Cortés).

La misma idea se repite en el versículo 7:137: «E hicimos que el pueblo que había sido humillado heredara las tierras orientales y occidentales, que Nosotros habíamos bendecido. Y se cumplió la bella promesa de tu Señor a los Hijos de Israel, por haber tenido paciencia. Y destruimos lo que Faraón y su gente habían hecho, lo que habían construido» (wa-awrațmà al-qawm alladìna kānū yustad̆ afüna mašāriq al-ard wa-magāriba-hā allatī baraknā fi-hā...).

Es evidente que el título de la crónica de Ibn Șāhịib al-ṣalāt es un calco de Corán 28:5. Propongo, pues, la siguiente traducción: «Don [divino] del imamato concedido a los que [previamente] habían sido humillados, pues Dios les ha hecho jefes (imames) y ha hecho de ellos los herederos (de sus opresores) $\gg{ }^{4}$. Como buen cortesano y fiel almohade, Ibn Șāhịib al-șalāt no sólo no pone en duda el derecho al califato de sus señores, sino que lo tiene por un derecho divino ${ }^{5}$.

4 E. Fricaud ha advertido la referencia coránica, pues remite a Corán 7:137 y 28:5, pero su traducción («Histoire du don de l'Imämat fait à des hommes considérés comme faibles mais que Dieu a constitués imām(s) et établis comme héritiers») no recoge, a mi modo de ver, el espíritu de esa referencia. V. su artículo «Les talaba dans la société almohade (Le temps d'Averroès)», Al-Qanțara XVIII (1997), 331-87, 334-5.

${ }^{5}$ Los almohades estaban convencidos no sólo de que Dios estaba de su parte, sino de que su gobierno equivalía al designio divino. Véase al respecto el reciente estudio de Vega Martín, Miguel, Peña Martín, Salvador y Feria García, Manuel C. El mensaje de las monedas almohades: numismática, traducción y pensamiento, col. Escuela de Traductores de Toledo, Servicio de Publicaciones de Castilla-La Mancha, 2002. 
El término mustad ${ }^{c} a f u ̄ n a$, del que se hará abundante uso entre los moriscos, pero con otro matiz ${ }^{6}$, aparece también en Corán 8:26. El título dado por Ibn Șāhịib al-ṣalāt a su crónica se vincula asimismo con este versículo, en el que se recuerda a los primeros musulmanes el largo camino recorrido desde que tuvieron que emigrar de La Meca a Medina:

¡Y recordad cuando erais pocos, humillados en el país, temerosos de que el enemigo os capturara! Entonces os procuró refugio, os fortaleció con su auxilio y

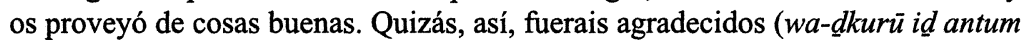
qalìl mustad̆ afün fí l-arḍ tajāfüna an yatajațtafa-kum al-nās fa-āwā-kum wa-ayyada-kum bi-nașri-hi wa-razaqa-kum min al-țayyibāt la alla-kum taškurūna).

Como los primeros musulmanes y el Profeta Muhammad, el Mahdī Ibn Tūmart y sus seguidores también tuvieron que emigrar, temerosos de la persecución de sus enemigos, y también lograron encontrar un refugio en el que se fortalecieron, de manera que lograron finalmente acabar con esos enemigos. La construcción de los inicios del movimiento almohade como un reflejo de la experiencia vital del Profeta Muhammad y sus Compañeros ha sido ya puesta de relieve ${ }^{7}$, de la misma manera que se ha señalado el lugar central que ocupa el Corán en la doctrina, ideología y propaganda almohades ${ }^{8}$. El título de la crónica de Ibn Șāhib al-ṣalāt no hace sino confirmar lo ya sabido, al tiempo que nos desvela una vez más la sutileza y complejidad de los recursos religiosos de legitimación manejados por los «intelectuales del régimen» almohade.

\footnotetext{
${ }^{6}$ El recogido, por ejemplo, en el versículo coránico 4:99, donde, tras haberse expuesto la obligación de emigrar de tierra infiel, se afirma: «Quedan exceptuados los débiles - hombres, mujeres y niños - que no disponen de posibilidades y no son dirigidos por el Camino». Sobre su uso en la polémica referente a la obligación de emigrar para los musulmanes andalusíes residentes en territorio cristiano v. van Koningsveld, P.S. y Wiegers, G. A., «The Islamic statute of the Mudejars in the light of a new source», Al-Qanțara XVII (1996), 19-58 y la bibliografia allí citada.

7 V. $\mathrm{EI}^{2}$, s.v. Ibn Tümart (J.F.P. Hopkins).

8 V. por ejemplo Martínez Núñez, M. A., «Epigrafía y propaganda almohades», Al-Qanțara XVIII (1997), 415-46.
} 